\title{
Linking Job Stress to Turnover Intention in Private Company: What is the Role of Leadership Style?
}

\author{
Dewiana Novitasari \\ Sekolah Tinggi Ilmu Ekonomi Insan Pembangunan, Indonesia
}

\begin{abstract}
This research aims to measure the effect of leadership style on turnover intention of a private company in Indonesia mediated by job stress. Data collection was carried out by simple random sampling to 253 population. The returned and valid questionnaire results were 147 samples. Data processing was using SEM method with SmartPLS 3.0 software. The results of this research are leadership style has a negative and significant effect on job stress and turnover intention. Job stress has a positive and significant effect on turnover intention. Job stress was not a mediator for the relationship between leadership style and turnover intention. This novel research is proposing a model to manage turnover intention among employees of a private company in Indonesia through leadership practice with job stress management as mediation. This research can pave the way to improve teacher readiness in facing the industrial revolution 4.0.
\end{abstract}

Keywords: Job stress, leadership style, organizational commitment, turnover intention

\section{INTRODUCTION}

Human resources is the main role for an organization or work environment (Asbari, Wijayanti, et al., 2019; Purwanto, Asbari, Fahlevi, et al., 2020; Setyowati Putri et al., 2020). This is important for organization or company to hire the best human resources. So to retain the human resources that are already exist are better than to recruit the new one. If there were someone who has their specialty and has intention to find another job, it will be hard for the company to find for the replacement. In the automotive field, it is important to retain the employee and the organization needs to conduct a research about why the employee has a desire to move out or turnover intention. Some researchers defines turnover intentions as an employee movement to left their organization (Ariyabuddhiphongs \& Kahn, 2017a; Mullen et al., 2018; Park \& Pierce, 2020; Ramalho Luz et al., 2018; Wong et al., 2015). Turnover can be a resignation, move out to another organization unit, and employee dismissal (Abouraia \& Othman, 2017; Alkhateri et al., 2018; Ariyabuddhiphongs \& Kahn, 2017a; Mullen et al., 2018; Park \& Pierce, 2020; Ramalho Luz et al., 2018; Wong et al., 2015). Turnover is not only an employee who move to another organization but also to another unit or other field that is still on the same organization (Ariyabuddhiphongs \& Kahn, 2017b). Employee who has turnover intention can be harmful for the organization because it can cause a negative impact for the organization, like instability and uncertainty towards the work condition.

There are many cause employee to take turnover intentions, leadership is one from all (Abouraia \& Othman, 2017; Ariyabuddhiphongs \& Kahn, 2017b). Leadership is process to influence other people to behave like what the leader wants. (Goestjahjanti et al., 2020; Silitonga et al., 2020; Sudiyono et al., 2020). A successful leadership is the one who succeed in achieve the organization goals without thinking whether the other felt resorted or not (Asbari, Santoso, et al., 2019; Bernarto et al., 2020; Fayzhall et al., 2020; Purwanto; et al., 2019; Purwanto et al., 2019; Purwanto, Asbari, Prameswari, \& Ramdan, 2020; Purwanto, Asbari, Prameswari, Ramdan, et al., 2020; Purwanto, Bernarto, Asbari, et al., 2020e, 2020f; Purwanto, Asbari, \& Hadi, 2020; Sudiyono et al., 2020). A leader has an important role because he is the one who take controlled and direct the organization (Hutagalung et al., 2020; Jumiran et al., 2020; Maesaroh et al., 2020; Novitasari, Asbari, et al., 2020; Novitasari, Sasono, et al., 2020; Nuryanti et al., 2020; Yuwono et al., 2020). A leadership is also important because it has a function to determine the organization goals (Asbari, 2015, 2018, 2019; Asbari, Fayzhall, Goestjahjanti, et al., 2020; Asbari, Purwanto, \& Budi, 2020; Asbari, Purwanto, et al., 2019; Asbari, Santoso, et al., 2019). One of a leader's roles in organization is intrapersonal, a role that is informational and a role to take a decision (Luthans, 2002). If they can play that role, the employee turnover intention will be low. In the intrapersonal role, a leader can gives 
motivation and direction when their employee are in trouble. The leader's presence can make the employee felt worth noting, so that there will be less turnover intentions. The result from a research proven that leader effectiveness negatively affected turnover intention (Park \& Pierce, 2020). The same result also mentioned that leadership has negative effect towards turnover intention (Ariyabuddhiphongs \& Kahn, 2017a). It means that the better leadership can reduce employee's turnover intention. Leadership can reduce turnover intention, but it also affected by job stress. Job stress can be harmful for the employee and at the end it will distract their work performance. Job stress is most likely happened to the organizational employee.

From the description above, variable that can reduce turnover intention in automotive industry is leadership. Thus, leadership can gives direct and indirect effect through job stress. There are many variables that related tu turnover intention, but so far those three variables are the real condition that happened from respondent. Therefore, researcher should conduct further research to prove whether leadership can affect job stress and turnover intention.

\section{LITERATURE REVIEW AND HYPOTHESIS DEVELOPMENT}

\section{A. Job Stress}

Human sources are the important roles in the organization, so every organization should manage a conducive work environmental so that the employee is free from the excessive job stress. Job stress is not only causing a bad work performance but also can cause employee to take turnover intention. (Sutardi et al., 2020). Job stress is a condition of tension that creates physical and psychic imbalances, which affect the emotions, thought processes, and conditions of employees (Rivai, 2014). Job stress is also defined as a condition of tension that affects a person's emotions, way of mind and physical condition (Siagian, 2017). Stress that is not properly addressed usually results in a person's inability to interact positively with their environment. According to Handoko (2008) stress is a condition in which an organization employee feels a strain that affects a person's thought process, emotions, and condition (Handoko, 2008). From the above understanding it can be concluded that stress is a condition felt by the employees of the organization both physically and psychically. Employees of organizations that feel stressed in their organizational environment usually feel an imbalance of physical and psychic conditions, thus impacting the thinking process, emotions, and condition of the organization's employees.

Robbins and Judge (2013) indicate of work stress into three aspects as follows:

1. Physiological indicators. This indicator can be seen from several things (a) Abdominal pain (b) Increased heart rate and shortness of breath (c) Increased blood pressure (d) Headache (e) Heart attack.

2. Psychological indicators. This indicator can be seen from several things (a) Anxiety (b) tension. (c) Boredom (d) dissatisfaction at work. (e) irritability. (f) procrastinating work.

3. Behavior indicator. This indicator can be seen from several things (a) Increased dependence on alcohol and cigarette consumption (b) Sabotage in the work. (c) Overeating or reducing unnatural eating as attractive behavior (d) Increased absenteeism rates and decreased work performance (e) Restlessness and sleep disturbances (f) Fast speech (Robbins \& Judge, 2013).

\section{B. Leadership}

Leaders play an important role in the organization. This role is not only in the internal sphere but also on the external sphere of the organization (Asbari, Fayzhall, et al., 2020; Asbari, Purwanto, et al., 2019, 2020; Asbari, Santoso, et al., 2019; Bernarto et al., 2020; Jumiran et al., 2020). Given the importance of this role, the task of the leader in an organization is not easy. Simply put, leadership is the process for directing and influencing activities related to the duties of the organization's employees (Prameswari et al., 2020; Yanthy et al., 2020). From this defenisi it appears that leadership is a process, not a person. but at its core kempemimpin is a force that can be used to influence others to perform deeds in the desired direction (Silitonga et al., 2020; Sudiyono et al., 2020; Waruwu et al., 2020). Broadly, leadership can be interpreted as an organized effort to manage and utilize human, materil and financial resources to achieve established goals. Similarly, Nawawi (2006) states that leadership in a structural context is interpreted as a process of influencing thoughts, feelings, behaviors, and directing all facilities to achieve the goals of the organization that has been set without the participation of its group employees formulating it. While in a non-structural context, leadership is defined as the process of influencing thoughts, feelings, behaviors, and directing all facilities to achieve common goals that have been set together (Nawawi \& Hadari, 1993). 
Other researchers suggest the dream is influence, if a person can increase his influence in others, they can lead more effectively (Robbins \& Judge, 2008). From some of the above, it can be concluded that leadership is an activity to influence others to work and willing to achieve common goals in an organization by utilizing all existing resources both human and non-human resources. Leadership indicators in this study will use leadership roles. If a leader has exercised his or her role in leading then it has carried out effective leadership. Leadership roles can be interpersonal, informational, and decision-making (Sutrisno, 2015). The three roles can be explained as follows:

1. Interpersonal role, One of the demands that a leader must meet is human skills. This interpersonal role consists of three forms, namely: First, as a symbol of the existence of the organization played in various activities that are legal and ceremonial such as attending various official ceremonies, fulfilling the invitation of subordinate and partner superiors. Second, as the leader responsible for motivating and giving direction to subordinates. Third, the role of liaison where a leader should be able to create a broad network by paying special attention to those who are able to do something for the organization as well as various parties who have the information needed by the organization.

2. Informational Role, Information is a crucial organising asset in its nature, because the organization's activities can be carried out efficiently and effectively without the support of up-to-date information, complete and trustworthy because it is well processed. The role consists of three forms, namely: First, a leader is a monitor of the flow of information that occurs from and into the organization. Second, the role of information divider. Information obtained by a leader other than useful in his leadership functions should also be channeled to other parties in the organization. Third, the role as a spokesperson for the organization. This role requires the ability to properly channel information to various parties outside the organization, especially when it comes to information about the plans, policies, actions, and results that have been achieved by the organization.

3. Decision making role, In this role there are three forms, namely, first as an entrepreneur. This role of a leader is expected to be able to continuously review the situation faced by the organization to achieve and find opportunities that can be utilized even though the study often demands changes in the organization. Both silencers. This role, among other things, means the willingness to assume responsibility to take corrective action if the organization faces serious disruptions that if not addressed will negatively impact the organization. The three dividing resources. This role is seen when a leader with his power or authority allocates funds and power. These include the authority to place a person in a particular position, the authority to promote a person, to demoted a person from office.

\section{Turnover Intention}

Turnover Intention from Rivai (2014) is an employee's desire to stop working from the organization or move to another workplace based on their choice. Turnover Intention is not good for the organization because they should do the process from the start to look for another employee. There should be a serious effort to reduce turnover intention. Turnover is an indication that the employee is not satisfied with the job. Turnover also can interfere the organization in economic way because they must put more expense to trained the new replacement. As Robbin (2006) said that turnover can increase recruitment cost, recruitment, and training. Moreover, it can disturb organization's management efficiency if the intellectual employee left the organization. Based on the definition from the expert, we can conclude that turnover intention is individual's desire to left the organization or move to the other better organization to expect better job. Turnover intention should be avoided because it increases organization's expense. There are some indicators that are used in this research (Mobley et al., 1978):

1. Thinking of Quitting. This condition is employee's reflection to think of quitting their job or choose to stay at their job. They began with dissatisfaction of work, and then the employee start to decide to quit their job.

2. Intention to search for alternative. This is the condition where the employee thinking of quitting their job to try a new job in other organization. If the employee often to think about it, they tend to find another job that they think it is better.

3. Intention to quit. This the condition where the employee wants to quit the job. This intention would be exist if the employee already found the other job. 


\section{Hypothesis Development}

\section{The Effect of Leadership towards Turnover Intention}

Leaders take the important role in the organization. This role is not only for the internal scope but also for the external scope of the organization (Sutrisno, 2015). Being a leader is not easy. Sutrisno (2015) said that leadership is a process to direct and influence the activity that related to the employee's job. Leadership as the indicator in this research use three ways of leadership, intrapersonal, informational, and decision making (Sutrisno, 2015). If the leader did a great role, it can reduce turnover intention. Previous research approved that leadership has a negative impact towards turnover intention (Elçi et al., 2012). So, that means a good leadership will reduce turnover intention and the first hypothesis is:

H1: Leadership has significant and negative effect to turnover intention.

\section{The Effect of Leadership towards Job Stress}

The previous study concluded that leadership has negative effect for job stress (Elçi et al., 2012). From the description and the previous research result the hypothesis is:

H2: Leadership has significant and negative effect to job stress.

\section{The Effect of Job Stress towards Turnover Intention}

Stress is both physically and psychic condition that are felt by employee. Employee that feel stress because of the organization usually because of the unbalanced physical and psychic and it affected how they think, emotion, and condition. Stress also has a positive impact (Sutardi et al., 2020). If the stress doesn't make the employee left the organization, it is a negative impact. Robbins dan Jugde (2013) mentioned that one of the factors that cause job stress is work demand. This factor includes individual work design (autonomy, diversity of tasks, automation level), work condition, and work physical layout. This result synchronized with the previous research that told job stress has a positive relation with turnover intention (Mullen et al., 2018). So, the hypothesis is:

H3: Job stress has significant and positive effect towards turnover intention.

\section{The Effect of Leadership towards Turnover Intention Through Job Stress}

Job Stress defined by Rivai (2014) is a condition that causes an unstable physical and psychic that affect emotion, way of thinking, and employee condition. The level of employee's job stress can be a physiological like (a) abdominal pain (b) increased heart rate and shortness of breath (c) increased blood pressure (d) headaches (e) heart attack. Stress in a form of psychological can be a (a) anxiety (b) tension (c) boredom (d) dissatisfaction in work (e) irritability (f) procrastinating, and stress in behavioural way is (a) addiction to alcohol and smoking (b) sabotage in work (c) overeating and reduce eating in extreme way (d) increased attendance rate (d) restless and sleeping problem (f) speak fast. Research result from Mullen et al., (2018) approved that that there is a positive and significant effect between job stress and turnover intention. From the theory dan the previous research, the hypothesis is:

H4: Leadership has significant and negative effect towards turnover intention through job stress.

\section{Conceptual Research Framework}

To proven the hypothesis and analyze the data, the conceptual research is in the Figure 1. 


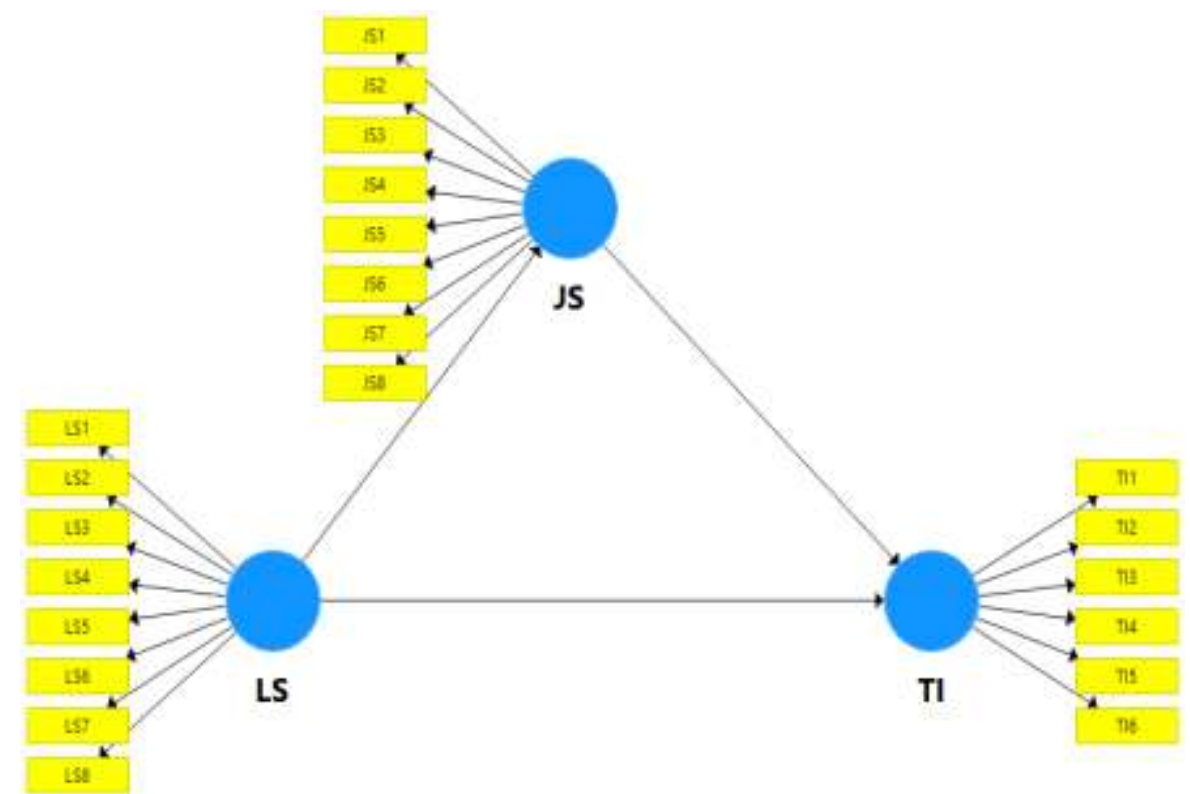

Figure 1. Research Model

III. RESEARCH METHOD

\section{A. Definition of Variable and Indicator Operational}

This research use quantitative method. The data collection is from the questionnaire that were distributed to all the lecturers in higher education. The instrument that is use to measure leadership style is adapted from Mintzberg theory (Luthans, 2002) with 8 items (LS1-LS8). Organizational commitment is adapted from (Allen \& Meyer, 1990) with 8 items (OC1-OC8). Job stress is adapted from (Robbins \& Judge, 2013) with 8 items (JS1-JS8). Turnover intention adapted from (Mobley et al., 1978) with 6 items (TI1-TI6). This research use closed questionnaire except for the question or statement about respondent identity. Each items are provided with 5 option: strongly agree (SS) score 5 , agree (S) score 4, undecided (KS) score 3, disagree (TS) score 2, and strongly disagree (STS) score 1. The method to process the date is use PLS and software SmartPLS version 3.0 as the tool.

\section{B. Population and Sample}

The population is 253 employees from automotive industry in Indonesia. The questionnaire is distributed with simple random sampling. There are 147 results that returned and valid. So, there is $58.1 \%$ sample from all the population.

IV. RESEARCH RESULT AND DISCUSSION

\section{A. Descriptive Sample}

Table1. Descriptive Sampe Information

\begin{tabular}{llll}
\hline Criteria & & Total & $\%$ \\
\hline Age & $<30$ years & 57 & $25.41 \%$ \\
& $30-40$ years & 104 & $46.60 \%$ \\
& $>40$ years & 63 & $27.99 \%$ \\
\hline Working time as employee & $<5$ years & 80 & $35.66 \%$ \\
& $5-10$ years & 109 & $48.52 \%$ \\
& $>10$ years & 35 & $15.82 \%$ \\
\hline Highest Degree & & & \\
& Bachellor Degree & 20 & $5.99 \%$ \\
& Senior High School & 211 & $94.01 \%$ \\
\hline
\end{tabular}




\section{B. Validity and Reliability Test Results of Research Indicators}

The testing phase of the measurement model includes convergent validity testing, discrimination validity. While to test the reliability of the construct used cronbach's alpha value and comALite reliability. The results of the PLS analysis can be used to test the research hypothesis if all indicators in the PLS model have qualified convergent validity, deskriminan validity and reliability test.

\section{Convergent Validity Testing}

The convergent validity test is carried out by looking at the loading factor value of each indicator against its construct. In most references, a factor weight of 0.5 or more is considered to have validation strong enough to explain a latent construct (Chin, 1998; Ghozali, 2014; Hair et al., 2010). In this study the minimum limit of loading factor received was 0.5, provided the AVE value of each construct > 0.5 (Ghozali, 2014).

Based on the processing results of SmartPLS 3.0, LS5, LS7, LS8, OC5, OC8, JS3, TI4 and TI6 must be dropped from the model, in order for all indicators to have a loading factor value above 0.5 and an AVE value above 0.5 . Thus, the convergent validity of this research model is already qualified. The loadings, cronbach's alpha, composite reliability and AVE values of each more construct can be seen in Figure 2 and Table 2 below:

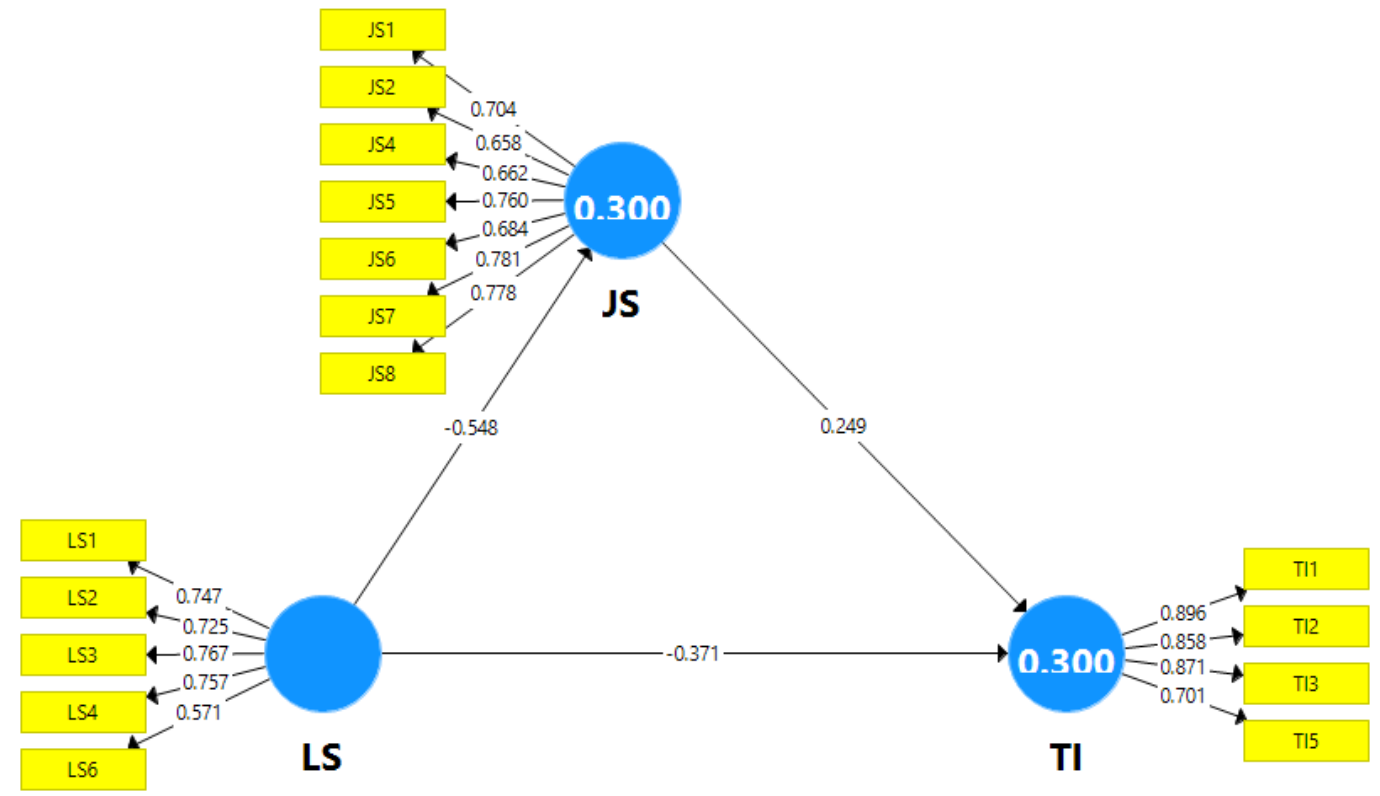

Figure 2. Research Model (Fit)

Table 2. Items Loadings, Cronbach's Alpha, Composite Reliability, and Average Variance Extracted (AVE)

\begin{tabular}{llllll}
\hline Variables & Items & Loadings & $\begin{array}{l}\text { Cronbach's } \\
\text { Alpha }\end{array}$ & $\begin{array}{l}\text { Composite } \\
\text { Reliability }\end{array}$ & AVE \\
\hline Leadership Style & LS1 & 0.747 & 0.762 & 0.840 & 0.514 \\
(LS) & LS2 & 0.725 & & & \\
& LS3 & 0.767 & & & \\
LS4 & 0.757 & & 0.518 \\
LS6 & 0.571 & & & \\
Job Stress & JS1 & 0.704 & 0.846 & & \\
& JS2 & 0.658 & & & \\
& JS4 & 0.662 & & & \\
& JS5 & 0.760 & & & \\
& JS6 & 0.684 & & & \\
& JS7 & 0.781 & & & \\
& JS8 & 0.778 & & & \\
& & & & & \\
\end{tabular}




\begin{tabular}{llllll}
\hline Turnover Intention & TI1 & 0.896 & 0.852 & 0.901 & 0.697 \\
(TI) & TI2 & 0.858 & & & \\
& TI3 & 0.871 & & & \\
& TI5 & 0.701 & & & \\
\hline
\end{tabular}

\section{Deskriminan Validity Testing}

Discriminant validity is performed to ensure that each concept of each latent variable is different from other latent variables. Models have good discriminant validity if the ave squared value of each exogenous construct (value on diagonal) exceeds the correlation between the construct and the other construct (value below diagonal) (Ghozali, 2014). The results of the discriminant validity test using ave squared values, i.e. by looking at the Fornell-Larcker Criterion Value obtained as mentioned in Table 3. The results of the deskriminan validity test in table 3 show that the entire construct already has an AVE square root value above the correlation value with other latent constructs (through the Fornell-Larcker criteria) so it can be concluded that the model has met the validity of the decriminal (Fornell \&amp; Larcker, 1981).

\section{Construct Reliability Testing}

Construct reliability can be assessed from cronbach's alpha and comALite reliability values from each construct. The recommended comALite reliability and cronbach's alpha values are more than 0.7 (Ghozali, 2014). The reliability test results in table 2 above show that the entire construct already has a composite reliability value and Cronbach's alpha is greater than $0.7(>0.7)$. In conclusion, the entire construct has fulfilled the required reliability.

\section{Hypothesis Testing}

Hypothesis testing in PLS is also referred to as the inner model test. These tests include tests of the significance of direct and indirect influences as well as measurements of the large influence of exogenous variables on endogenous variables. To know the effect of authentic leadership on the performance of lecturers with variable mediation of lecturer engagement requires a direct and indirect influence test. Influence tests are conducted using t-statistical tests in a partial least squared (PLS) analysis model using the help of SmartPLS 3.0 software. With boothstrapping techniques, R Square values and significance test scores are obtained as shown in the table below:

Tabel 3. Discriminant Validity

\begin{tabular}{llll}
\hline Variables & JS & LS & TI \\
\hline JS & $\mathbf{0 . 7 2 0}$ & & \\
LS & -0.548 & $\mathbf{0 . 7 1 7}$ & \\
TI & 0.452 & -0.507 & $\mathbf{0 . 8 3 5}$ \\
\hline
\end{tabular}

Table 4. R Square Value

\begin{tabular}{lll}
\hline & R Square & R Square Adjusted \\
\hline JS & 0.300 & 0.295 \\
TI & 0.300 & 0.291 \\
\hline
\end{tabular}


Table 5. Hypotheses Testing

\begin{tabular}{lllllll}
\hline Hypotheses & Relationship & Beta & SE & T Statistics & P-Values & Decision \\
\hline H1 & LS -> TI & -0.371 & 0.112 & 3.326 & 0.001 & Supported \\
H2 & LS -> JS & -0.548 & 0.059 & 9.251 & 0.000 & Supported \\
H3 & JS -> TI & 0.249 & 0.108 & 2.293 & 0.022 & Supported \\
H4 & LS -> JS -> TI & -0.136 & 0.062 & 2.184 & 0.029 & Supported \\
\hline
\end{tabular}

Based on Table 4 above, the R Square job stress (JS) value of 0.336 means that the job stress (JS) variable is able to be explained by leadership style (LS) and organizational commitment (OC) variables of 33.6\%, while the remaining $66.4 \%$ is explained by other variables not discussed in this study. Meanwhile, the R Square turnover intention (IT) value of 0.315 means that the turnover intention (TI) variable can be explained by variable stress (JS) leadership style (LS) and organizational commitment (OC) of 31.5\%, while the remaining 69.5\% is explained by other variables not discussed in this study. While Table 5 displays T Statistics and P-Values that show the influence between the research variables mentioned.

\section{Discussion}

\section{The Effect Leadership Style towards Turnover Intention}

From the hypothesis in Table 5 we know that there is significant and negative effect of leadership style towards turnover intention. This is approved with the level of sig. 0,0001 $(\mathrm{P}<0.05)$. The coefficient is negative $-0,371$. The negative coefficient showed that the more leadership style, the less turnover intention. The research result support the previous research by Elçi et al., 2012) wheren the result drawn a conclusion there is negative and significant relation between transformational leadership style and turnover intention. The research also support the previous research by Nyoman and Deniartha (2016) approved that leadership style has a negative impact for turnover intention (Nyoman \& Deniartha, 2016). It means that leadership style should run smoothly to reduce turnover intention. A leader also take a controll in organization. The role is not only for the internal but also external (Sutrisno, 2015). The importance of the leader's role, being a leader is not easy. Leadership style is embodied with leadership style that directed and influenced the activiteis whis related to employee's job.

\section{The Effect of Leadership Style towards Job Stress}

From the result, leadership style variable has $9.251 \mathrm{t}$-statistics with $0,000(\mathrm{p}<0.05)$ sig.t. Leadership style is approved to has a significant and negative effect towards job stress. The researh result support the previous research by (Elçi et al., 2012) that concluded leadership style has a negative impact for job stress. The result showed that leaders in private company can do their role. Sutrisno (2015) mentioned decision taking is the leader's role. There are three roles, the first is entrepreneur. This role expects leaders to studying more about the situation that the organization has to encounter to achieve their goal and find a chance although it can causes a change. The second is silencer. This role expects leaders to take the responsibility to take a corrective action. The third is dividing funds and resources. Leaders has power and authority to take care of the funds and resources. Including an authority to hire new employee, to promote employee, and lowering the position. So the implementation of the role of leaders in decision making by itself can reduce the stress level of employee work. As a silencer of the emerging problem, a leader is willing to assume the responsibility to take corrective action if the organization faces serious disruptions that otherwise will negatively impact the organization. Thus the level of work stress felt by employees can be reduced if the leader has done his or her role well.

\section{The Effect of Turnover Intention towards Job Stress}

Based on the test, leadership style variable has $2.293 \mathrm{t}$-statistic value with 0,022 sig.t $(\mathrm{p}<0.05)$. This is proven that job stress variable has significant and positive impat towards turnover intention. The result showed the higher the stress, the desire to left out will follow. Stress is a condition that is felt by the employee both in 
physical and psychic way. Employee who feel stress in their organization environment usually felt the unbalance condition physical and psychic that affected on how they think, emotion and condition. Stress is not only be a negative effect but also positive. Stress considered as negative if it makes the employee left the organization (Luthans, 2002). Robbins \& Judge (20130) mentioned that one of the factors that causes job stress is work demand. Factor that inclused individual work (autonomy, diversity of tasks, and automatic level), work condition and work physical layout. The result is syncronize with a research by Mosadeghrad (20130), job stress can be a positive relation towards turnover relation. The result showed that job stress can causes employee to have turnover intention.

\section{The Effect of Leadership Style towards Turnover Intention Through Job Stress.}

The result from data analysis showed that direct effect between leadership style towards turnover intention has minus $-0,371$ coefficient, and the indirect effect through job stress is $(-0,548)$ and the coefficient of job stress towards turnover intention is $(0,249)$. From this result we know that direct coefficient is bigger that the indirect effect, so the effect between leadership style towards turnover intention is direct effect without job stress. The result gave information that turnover intention will be higher if the job stress level is also high. The excessive stress can cause turnover intention. Also happened if the leadership style is better, and the level stress is also high there will be many turnover intention

\section{CONCLUSION AND SUGGESTION}

\section{A. Conclusion}

This study contributes to the scientific literature on turnover intention by developing and validating research models that describe the role of leadership style, organizational commitment and job stress in the automotive industry in Indonesia. This study can be useful for company management to strategize in developing a competent workforce, committing well with the organization and providing a competitive edge. Corporate organizations need to always look for ways that existing employees can manage and manage work stress by getting positive support from leaders and organizations. Positive Results in the form of leadership style support and organizational commitment should provide sufficient encouragement to minimize work stress levels. This study examines only a few variables, future research may expand the number of variables in this model. Additional variables such as awards and recognition, job satisfaction, etc. can also be considered to be explained in future research. This research is limited to the context of the automotive industry, studies in other types of industries can be conducted to see if there are variations in results and other conclusions.

\section{B. Suggestion}

From the results of the study and conclusions then the advice submitted is as follows: First, work stress is the main cause of turnover intention, for that improvement in terms of leadership and organizational commitment will not be able to reduce turnover intention if work stress is not immediately ed. Therefore, the necessary thing to reduce turnover intention is to reduce the level of work stress. Second, the work stress variables in this study lead more to work stress that negatively impacts, so further research can use work stress that has a positive impact.

\section{REFERENCE}

[1] Abouraia, M. K., \& Othman, S. M. (2017). Transformational Leadership, Job Satisfaction, Organizational Commitment, and Turnover Intentions: The Direct Effects among Bank Representatives. American Journal of Industrial and Business Management, 07(04), 404423. https://doi.org/10.4236/ajibm.2017.74029

[2] Agistiawati, E., Asbari, M., Basuki, S., Yuwono, T., \& Chidir, G. (2020). Exploring the Impact of Knowledge Sharing and Organizational Culture on Teacher Innovation Capability. International Journal of Science and Management Studies (IJSMS), 3(3), 62-77. http://www.ijsmsjournal.org/volume3-issue3.html

[3] Alkhateri, A. S., Khalifa, G. S. A., \& Ameen, A. (2018). The Impact of Perceived Supervisor Support on Employees Turnover Intention: The Mediating Role of Job Satisfaction and Affective Organizational Commitment Total Quality Management Practices View project The Impact of Emotional Intelligence on Work Life Ba. 12(December), 477-492. https://doi.org/10.3923/ibm.2018.477.492

[4] Allen, N. J., \& Meyer, J. P. (1990). The measurement and antecedents of affective, continuance and normative commitment to the organization. Journal of Occupational Psychology, 63, 1-18. https://doi.org/https://doi.org/10.1111/j.2044-8325.1990.tb00506.x 
[5] Ariyabuddhiphongs, V., \& Kahn, S. I. (2017a). Transformational leadership and turnover intention $\square$ : The mediating effects of rust and job performance on café employees in Thailand. Journal of Human Resources in Hospitality \& Tourism, 16(2), 215-233. https://doi.org/10.1080/15332845.2016.1202730

[6] Ariyabuddhiphongs, V., \& Kahn, S. I. (2017b). Transformational leadership and turnover intention: The mediating effects of trust and job performance on café employees in Thailand. Journal of Human Resources in Hospitality and Tourism, 16(2), 215-233. https://doi.org/10.1080/15332845.2016.1202730

[7] Asbari, M. (2015). Fokus Satu Hebat. Penerbit Dapur Buku.

[8] Asbari, M. (2018). Ayah tanpa Wajah. Penerbit Tosca.

[9] Asbari, M. (2019). Pengaruh kepemimpinan transformasional dan iklim organisasi terhadap kinerja dosen. JOCE IP, 13(2), $172-186$. http://jurnal.ipem.ac.id/index.php/joce-ip/article/view/187

[10] Asbari, M., Fayzhall, M., Goestjahjanti, F. S., Winanti, Yuwono, T., Hutagalung, D., Basuki, S., Maesaroh, S., Mustofa, Chidir, G., Yani, A., \& Purwanto, A. (2020). Peran Kepemimpinan Transformasional Dan Organisasi Pembelajaran Terhadap Kapasitas Inovasi Sekolah. EduPsyCouns: Journal of Education, Psychology and Counseling, 2(1), 6724-6748. https://ummaspul.ejournal.id/Edupsycouns/article/view/421

[11] Asbari, M., Purwanto, A., \& Budi, P. (2020). Pengaruh Iklim Organisasi dan Kepemimpinan Transformasional Terhadap Produktivitas Kerja Inovatif Pada Industri Manufaktur di Pati Jawa Tengah . Jurnal Produktivitas, 7(1), 62-69. https://doi.org/http://dx.doi.org/10.29406/jpr.v7i1.1797

[12] Asbari, M., Purwanto, A., \& Santoso, P. B. (2019). Influence of Leadership, Motivation, Competence, Commitment and Culture on ISO 9001:2015 Performance in Packaging Industry. Scholars Journal of Economics, Business and Management, 6(12), 577-582. https://doi.org/10.36347/sjebm.2019.v06i12.005

[13] Asbari, M., Santoso, P. B., \& Purwanto, A. (2019). Pengaruh Kepemimpinan dan Budaya Organisasi Terhadap Perilaku Kerja Inovatif pada Industri 4.0. Jim UPB, 8(1), 7-15. https://doi.org/ttps://doi.org/10.33884/jimupb.v8i1.1562

[14] Asbari, M., Wijayanti, L. M., Hyun, C. C., Purwanto, A., Santoso, B., \& Article, H. (2019). Effect of Tacit and Explicit Knowledge Sharing on Teacher Innovation Capability. Dinamika Pendidikan, 14(2), 227-243. https://doi.org/10.15294/dp.v14i2.22732

[15] Bernarto, I., Bachtiar, D., Sudibjo, N., Suryawan, I. N., Purwanto, A., \& Asbari, M. (2020). Effect of transformational leadership, perceived organizational support, job satisfaction toward life satisfaction: Evidences from indonesian teachers. International Journal of Advanced Science and Technology, 29(3), 5495-5503. http://sersc.org/journals/index.php/IJAST/article/view/6057

[16] Chin, W. (1998). The Partial Least Squares Approach to Structural Equation Modeling (E. Modern Methods for Business Research, In: G. A. Marcoulides (ed.)). Lawrence Erlbaum Associates Publisher.

[17] Elçi, M., Şener, İ., Aksoy, S., \& Alpkan, L. (2012). The impact of ethical leadership and leadership effectiveness on employees' turnover intention: The mediating role of work related stress. Procedia-Social and Behavioral Sciences, 58, $289-297$.

[18] Fayzhall, M., Asbari, M., Purwanto, A., Goestjahjanti, F. S., Yuwono, T., Radita, F. R., Yulia, Y., Cahyono, Y., \& Suryani, P. (2020). Transformational versus Transactional Leadership: Manakah yang Mempengaruhi Kepuasan Kerja Guru? EduPsyCouns: Journal of Education, Psychology and Counseling, 2(1), 256-275. https://ummaspul.e-journal.id/Edupsycouns/article/view/463

[19] Fornell, C., \& Larcker, D. F. (1981). Evaluating Structural Equation Models with Unobservable Variables and Measurement Error. Journal of Marketing Research, 18(1), 39. https://doi.org/10.2307/3151312

[20] Ghozali, I. (2014). Structural Equation Modeling, Metode Alternatif dengan Partial Least Square (PLS) (4th ed.). Badan Penerbit Universitas Diponegoro.

[21] Goestjahjanti, S. F., Novitasari, D., Hutagalung, D., Asbari, M., \& Supono, J. (2020). Impact of Talent Management, Authentic Leadership and Employee Engagement on Job Satisfaction: Evidence From South East Asian Industries. Journal of Critical Reviews, 7(19), 67-88. http://www.jcreview.com/?mno=101983

[22] Hair, J. F., Black, W. C., Babin, B. J., \& Anderson, R. E. (2010). Multivariate Data Analysis (7th ed.). Pearson Prentice Hall.

[23] Handoko, T. H. (2008). Manajemen Personalia dan Sumber Daya. Manusia (Edisi 2). Yogyakarta: BPFE.

[24] Hutagalung, D., Asbari, M., Fayzhall, M., Ariyanto, E., Agistiawati, E., Sudiyono, R. N., Waruwu, H., Goestjahjanti, F. S., Winanti, \& Yuwono, T. (2020). Peran Religiusitas, Kepemimpinan Transformasional, Kepuasan Kerja dan Mediasi Organizational Citizenship Behavior terhadap Kinerja Guru. EduPsyCouns: Journal of Education, Psychology and Counseling, 2(1), 311-326. https://ummaspul.e-journal.id/Edupsycouns/article/view/483

[25] Jumiran, Novitasari, D., Nugroho, Y. A., Sutardi, D., Sasono, I., \& Asbari, M. (2020). Pengaruh Dimensi Kepemimpinan Transformasional terhadap Kepuasan Kerja dan Komitmen Organisasional: Studi Kasus pada Dosen Perguruan Tinggi Swasta. EduPsyCouns: Journal of Education, Psychology and Counseling, 2(1), 600-621. https://ummaspul.ejournal.id/Edupsycouns/article/view/555

[26] Luthans, F. (2002). Organizations Behavior. McGraw Hill International: John E. Biernat.

[27] Maesaroh, S., Asbari, M., Hutagalung, D., Agistiawati, E., Basuki, S., Radita, F. R., Nurasiah, Yulia, Y., Singgih, E., \& Chidir, G. (2020). Pengaruh Religiusitas dan Kepemimpinan Transformasional terhadap Kinerja Guru melalui Mediasi Organizational 
Citizenship Behavior. EduPsyCouns: Journal of Education, Psychology and Counseling, 2(1), 276-290. https://ummaspul.ejournal.id/Edupsycouns/article/view/473

[28] Mobley, W. H., Horner, S. O., \& Hollingsworth, A. T. (1978). An evaluation of precursors of hospital employee turnover. Journal of Applied Psychology, 63(4), 408-414. https://doi.org/10.1037/0021-9010.63.4.408

[29] Mullen, P. R., Malone, A., Denney, A., \& Dietz, S. S. (2018). Job Stress, Burnout, Job Satisfaction, and Turnover Intention Among Student Affairs Professionals. College Student Affairs Journal, 36(1), 94-108. https://doi.org/https://doi.org/10.1353/csj.2018.0006

[30] Nawawi, H., \& Hadari, M. M. (1993). Kepemimpinan yang efektif. Gadjah Mada Press.

[31] Novitasari, D., Asbari, M., Sutardi, D., GazalI, \& Silitonga, N. (2020). Mempertahankan Kinerja Karyawan di Masa Pandemi Covid19: Analisis Kesiapan untuk Berubah dan Efektivitas Kepemimpinan Transformasional. Value: Jurnal Manajemen Dan Akuntansi, 15(2), 22-37. https://doi.org/https://doi.org/10.32534/jv.v15i2.1152

[32] Novitasari, D., Asbari, M., Wijaya, M. R., \& Yuwono, T. (2020). Effect of Organizational Justice on Organizational Commitment: Mediating Role of Intrinsic and Extrinsic Satisfaction. International Journal of Science and Management Studies (IJSMS), 3(3), 96112. http://www.ijsmsjournal.org/volume3-issue3.html

[33] Novitasari, D., Sasono, I., \& Asbari, M. (2020). Work-Family Conflict and Worker's Performance during Covid-19 Pandemic: What is the Role of Readiness to Change Mentality? International Journal of Science and Management Studies (IJSMS), 3(4), 122-134. http://www.ijsmsjournal.org/volume3-issue4.html

[34] Novitasari, D., Sasono, I., Santoso, J., Sudiyono, R. N., \& Asbari, M. (2020). Pengaruh Kesiapan untuk Berubah pada Karyawan Manufaktur: Analisis Praktik Kepemimpinan di Masa Pandemi Covid-19. JUMBO (Jurnal Manajemen , Bisnis Dan Organisasi ), 4(1), 175-188. https://doi.org/http://dx.doi.org/10.33772/jumbo.v4i1.13260

[35] Nuryanti, Y., Novitasari, D., Nugroho, Y. A., Fauji, A., Gazali, \& Asbari, M. (2020). Meningkatkan Komitmen Organisasional Dosen: Analisis Pengaruh Kepemimpinan Perguruan Tinggi dan Kepuasan Intrinsik \& Ekstrinsik Dosen. EduPsyCouns: Journal of Education, Psychology and Counseling, 2(1), 561-581. https://ummaspul.e-journal.id/Edupsycouns/article/view/551

[36] Nyoman, S. N., \& Deniartha, I. (2016). Peran Kepemimpinan, Komitmen Organisasi, Trunover Intention, Kepuasan Kerja dan Kinerja Karyawan LPD Desa Adat Tanjung Benoa-Badung. Jurnal Manajemen \& Bisnis, 13(3), 120-130.

[37] Park, T., \& Pierce, B. (2020). Impacts of transformational leadership on turnover intention of child welfare workers. Children and Youth Services Review, 108, 104624. https://doi.org/10.1016/j.childyouth.2019.104624

[38] Prameswari, M., Asbari, M., Purwanto, A., Ong, F., Kusumaningsih, S. W., Mustikasiwi, A., Chidir, G., Winanti, \& Sopa, A. (2020). The impacts of leadership and organizational culture on performance in indonesian public health: The mediating effects of innovative work behavior. International Journal of Control and Automation, 13(2), 216-227. http://sersc.org/journals/index.php/IJCA/article/view/7630

[39] Purwanto, A., Asbari, M., \& Hadi, A. H. (2020). Gaya Kepemimpinan Perguruan Tinggi Kesehatan: Authentic, Tansformational, Authoritarian atau Transactional. Surya Medika Jurnal Ilmiah Ilmu Keperawatan Dan Ilmu Kesehatan Masyarakat, 15(1), 8-18. https://doi.org/10.32504/sm.v15i1.163

[40] Purwanto, A., Asbari, M., Fahlevi, M., Mufid, A., Agistiawati, E., Cahyono, Y., \& Suryani, P. (2020). Impact of Work From Home ( WFH ) on Indonesian Teachers Performance During the Covid-19 Pandemic $\square$ : An Exploratory Study. International Journal of Advanced Science and Technology, 29(5), 6235-6244. http://sersc.org/journals/index.php/IJAST/article/view/15627

[41] Purwanto, A., Asbari, M., Prameswari, M., \& Ramdan, M. (2020). Gaya Kepemimpinan Di Madrasah Aliyah: Authentic, Tansformational, Authoritarian Atau Transactional? Nidhomul Haq, 5, 15-31. https://doi.org/10.31538/ndh.v5i1.544

[42] Purwanto, A., Asbari, M., Prameswari, M., Ramdan, M., \& Setiawan, S. (2020). Dampak Kepemimpinan, Budaya Organisasi dan Perilaku Kerja Inovatif Terhadap Kinerja Pegawai Puskesmas. Jurnal Ilmu Kesehatan Masyarakat, 9(01), 19-27. https://doi.org/10.33221/jikm.v9i01.473

[43] Purwanto, A., Asbari, M., Santoso, P. B., Wijayanti, L. M., Hyun, C. C., \& Pramono, R. (2020). Effect of Application ISO $38200: 2018$ Chain of Wood Products Custody toward Paper Company Competitiveness in Borneo Island Indonesia. International Journal of Science and Management Studies (IJSMS), April, 28-35. http://www.ijsmsjournal.org/2020/volume-3 issue-2/ijsms-v3i2p104.pdf

[44] Purwanto, A., Bernarto, I., Asbari, M., Mayesti Wijayanti, L., \& Chi Hyun, C. (2020e). Effect of Transformational and Transactional Leadership Style on Public Health Centre Performance. Journal of Reseacrh in Business, Economics, and Education, 2(1), 304-314. http://e-journal.stie-kusumanegara.ac.id

[45] Purwanto, A., Bernarto, I., Asbari, M., Wijayanti, L. M., Choi, \&, \& Hyun, C. (2020f). The Impacts of Leadership and Culture on Work Performance in Service Company and Innovative Work Behavior As Mediating Effects. Journal of Reseacrh in Business, Economics, and Education, 2(1), 283-291. http://e-journal.stie-kusumanegara.ac.id

[46] Purwanto, A., Mayesti Wijayanti, L., Chi Hyun, C., \& Asbari, M. (2019). the Effect of Tansformational, Transactional, Authentic and Authoritarian Leadership Style Toward Lecture Performance of Private University in Tangerang. DIJDBM, 1(1), 29-42. https://doi.org/10.31933/DIJDBM

[47] Purwanto;, A., Asbari;, M., \& Santoso, P. B. (2019). Pengaruh Kompetensi, Motivasi, Kepemimpinan, Komitmen dan Budaya Kerja Sistem Manajemen Integrasi ISO 9001, ISO 14000 dan ISO 45001 pada Industri Otomotif. Jurnal Produktivitas, 6(2), $158-166$. http://openjurnal.unmuhpnk.ac.id/index.php/jp/article/view/1798 
[48] Putra, A. S., Novitasari, D., Asbari, M., Purwanto, A., Iskandar, J., Hutagalung, D., \& Cahyono, Y. (2020). Examine Relationship of Soft Skills, Hard Skills, Innovation and Performance: the Mediation Effect of Organizational Learning. International Journal of Science and Management Studies (IJSMS), 3(3), 27-43. http://www.ijsmsjournal.org/2020/volume-3 issue-3/ijsms-v3i3p104.pdf

[49] Ramalho Luz, C. M. D., Luiz de Paula, S., \& de Oliveira, L. M. B. (2018). Organizational commitment, job satisfaction and their possible influences on intent to turnover. Revista de Gestão, 25(1), 84-101. https://doi.org/10.1108/rege-12-2017-008

[50] Rivai, V. (2014). Manajemen Sumber Daya Manusia untuk Perusahaan, Edisi ke 6, PT. Raja Grafindo Persada, Depok, 16956.

[51] Robbins, S. P., \& Judge, T. A. (2008). Organizational Behavior. Prentise Hall.

[52] Robbins, S. P., \& Judge, T. A. (2013). Organizational Behavior. Pearson Education Inc.

[53] Setyowati Putri, R., Purwanto, A., Pramono, R., Asbari, M., Mayesti Wijayanti, L., \& Chi Hyun, C. (2020). Impact of the COVID-19 Pandemic on Online Home Learning: An Explorative Study of Primary Schools in Indonesia. International Journal of Advanced Science and Technology, 29(5), 4809-4818. http://sersc.org/journals/index.php/IJAST/article/view/13867

[54] Siagian, S. P. (2017). Manajemen sumber daya manusia. Bumi Aksara.

[55] Silitonga, N., Novitasari, D., Sutardi, D., Sopa, A., Asbari, M., Yulia, Y., Supono, J., \& Fauji, A. (2020). The Relationship of Transformational Leadership, Organizational Justice and Organizational Commitment: a Mediation Effect of Job Satisfaction. Journal of Critical Reviews, 7(19), 89-108. http://www.jcreview.com/?mno=101999

[56] Sudiyono, R. N., Fikri, M. A. A., Asbari, M., Suroso, Nugroho, Y. A., \& Singgih, E. (2020). The Role of Employee Engagement in the Relationship between Authentic Leadership, Talent Management and Job Satisfaction. International Journal of Advanced Science and Technology, 29(5), 11809-11836. http://sersc.org/journals/index.php/IJAST/article/view/25377

[57] Sutardi, D., Novitasari, D., Asbari, M., Silitonga, N., Nugroho, Y. A., Hutagalung, D., Mustofa, Chidir, G., Basuki, S., \& Yuwono, T. (2020). Pengaruh Work-Family Conflict, Stres Kerja dan Social Support terhadap Kepuasan Kerja: Studi Kasus pada Guru Wanita di Tangerang. EduPsyCouns: Journal of Education, Psychology and Counseling, 2(1), 482-498. https://ummaspul.ejournal.id/Edupsycouns/article/view/513

[58] Sutrisno, E. (2015). Manajemen Sumber Daya Manusia (Cetakan ke tujuh). Jakarta: Kencana Prenada Media Group.

[59] Waruwu, H., Asbari, M., Purwanto, A., Nugroho, Y. A., Fikri, M. A. A., Fauji, A., Shobihi, A. W. I., Hulu, P., Sudiyono, R. N., Agistiawati, E., \& Dewi, W. R. (2020). The Role of Transformational Leadership, Organizational Learning and Structure on Innovation Capacity: Evidence from Indonesian Private Schools. EduPsyCouns: Journal of Education, Psychology and Counseling, 2(1), 378-397. https://ummaspul.e-journal.id/Edupsycouns/article/view/499

[60] Wong, Y., Wong, Y.-W., \& Wong, C. (2015). An integrative model of turnover intention: Antecedents and their effects on employee performance in Chinese joint ventures. Journal of Chinese Human Resource Management, 6(1), 71-90. https://doi.org/http://dx.doi.org/10.1108/JCHRM-06-2014-0015

[61] Yanthy, E., Purwanto, A., Pramono, R., Cahyono, Y., \& Asbari, M. (2020). Pengaruh Gaya Kepemimpinan Transformasional dan Tranksaksional Terhadap Kinerja Sistem Jaminan Halal HAS 23000. Jurnal Bisnis Dan Manajemen Islam, 8(1), 131-153. https://doi.org/http://dx.doi.org/10.21043/bisnis.v8i1.7045

[62] Yuwono, T., Wiyono, N., Asbari, M., Novitasari, D., \& Silitonga, N. (2020). Analisis Pengaruh Efektivitas Kepemimpinan Transformasional dan Kesiapan untuk Berubah terhadap Kinerja Karyawan Wanita di Masa Pandemi Covid-19. Jurnal Ilmiah Mahasiswa Ekonomi Manajemen, 5(3), 615-632. http://www.jim.unsyiah.ac.id/EKM/article/view/15502 